Trinity University

Digital Commons @ Trinity

Health Care Administration Faculty Research

Health Care Administration

$10-2001$

\title{
The Earnings and Employment of Nurses in an Era of Cost Containment
}

Edward J. Schumacher

TrinityUniversity, eschumac@trinity.edu

Follow this and additional works at: https://digitalcommons.trinity.edu/hca_faculty

Part of the Health and Medical Administration Commons

\section{Repository Citation}

Schumacher, E.J. (2001). The earnings and employment of nurses in an era of cost containment. Industrial and Labor Relations Review, 55(1), 116-132. doi: 10.1177/001979390105500107

This Article is brought to you for free and open access by the Health Care Administration at Digital Commons @ Trinity. It has been accepted for inclusion in Health Care Administration Faculty Research by an authorized administrator of Digital Commons @ Trinity. For more information, please contact jcostanz@trinity.edu. 


\title{
THE EARNINGS AND EMPLOYMENT OF NURSES IN AN ERA OF COST CONTAINMENT
}

\author{
EDWARD J. SCHUMACHER*
}

\begin{abstract}
Previous research has shown that from the 1980s through the early 1990s, nurses enjoyed substantial wage and employment gains that stemmed, to some extent, from increased labor demand. Using individual data for 1988-98 to compare nurses' fortunes with those of college-educated women and other workers in the health care industry, the author documents that nurses experienced a decline in real wages beginning in the early 1990s, at the same time that the skill premium for RNs, as reflected by the return to education and experience, was increasing. Changes in measured characteristics and their returns explain very little of the decline, consistent with the theory that the relative wage decrease was driven by a decline in the demand for RNs and increased cost constraints. The effects of HMO penetration are found to explain only a small part of the variation in wages across metropolitan statistical areas and across time.
\end{abstract}

$\mathbf{P}$ revious research on the labor market for nurses has demonstrated substantial wage and employment gains for nurses during the 1980s and into the early 1990s (Schumacher 1997; Walton 1997; Krall 1995). For example, registered nurses (RNs) earned about $42 \%$ higherwages than college-educated women in 1993, compared to $11 \%$ higher wages in 1975 (Schumacher 1997). Licensed practical nurses (LPNs) made similar gains when compared to women with between 13 and 15 years of schooling. The relative and absolute wage gains in nursing are thought to have been driven by demand increases due to changes

*Edward J. Schumacher is Associate Professor, Department of Economics, East Carolina University. He appreciates helpful comments and assistance from Barry Hirsch and Laurence Baker. The CPS data sets used in this paper were developed with the assistance of David Macpherson and Barry Hirsch. in heal th care technology, hospital staffing patterns, and public and private third party reimbursement policy.

Beginning in the early 1990s, the growth in nursing wages appears to have slowed. The relative wage differential between RNs and women with college degrees in nonheal th professions fell from $42 \%$ in 1993 to $27 \%$ in 1994 (Schumacher 1997). This decrease coincided with a slowdown in the growth of health care expenditures and rapid changes in the structure of the insurance industry.

Previous research has not examined the earnings and employment of nursing personnel past the early 1990s. In this paper I extend this research by examining how the

Copies of the computer programs used to generate the results presented in the paper are available from the author at Department of Economics, East Carolina University, Greenville, NC 27858.

Industrial and Labor Relations Review, Vol. 55, No. 1 (October 2001). (C) by Cornell University. $0019-7939 / 00 / 5501 \$ 01.00$ 
changes in the heal th care industry influenced the earnings and employment of nurses through 1998. Authors of previous studies have speculated that the increased earnings and employment were driven largely by changes in demand, but they have not been able to identify this link precisely, due, in part, to the change being in one direction. I examine the role of demand factors by observing $\mathrm{RN}$ wages and employment over a period of both reduced growth in heal th care expenditures overall and slower growth in hospital expenditures than in non-hospital expenditures with imperfect or slow substitution between sectors.

I first examine the earnings and employment patterns of registered nurses over the 1988-98 period. Comparing RNs to appropriate non-nursing comparison groups allows a control for economy-wide and industry-wide changes in earnings and an examination of how nurses' relative earnings have evolved. In addition, examining employment patterns in and out of hospitals allows further insight into the response of these labor markets to changes in the heal th care industry. I next examine the source of decline in RN relative wages between 1993 and 1998 by decomposing the fall in relative wages into the portion due to changes in characteristics and the portion due to changes in the returns to those characteristics. Finally, I examine the impact on RN wages of managed care's presence in metropolitan areas.

\section{Background and Data}

\section{Background}

Health expenditures have risen rapidly over the past twenty years. In 1980, real heal th expenditures were $\$ 489.2$ billion in 1998 dollars, or $8.9 \%$ of GDP; by 1998 , that figure had increased to $\$ 1,149.1$ billion, or $13.5 \%$ of GDP (Health Care Financing Administration). Since the early 1990s, however, growth has slowed. Health expenditures as a percentage of GDP have remained relatively constant since 1992, and the percentage change in expendi- tures has decreased to about $5 \%$ per year.

This slowdown in expenditures has been accompanied by a slowdown in employment and earnings in the health services industry (Engel 1999). Between 1987 and 1992 job growth in the health services industry averaged $4.6 \%$ per year, while the growth in overall services averaged $3.8 \%$ per year. Between 1992 and 1997, however, job growth in heal th services averaged $2.7 \%$ while growth averaged $4.4 \%$ in all service industries. The one exception to this trend was the home health industry, in which employment growth averaged $12.7 \%$ between 1992 and 1997. Due to changes in federal reimbursement policy in 1998, however, employment growth in this sector fell to $-4.5 \%$ (Engel 1999, Table 1).

It is believed that one of the main contributors to this slowdown in expenditures and employment is the emerging dominance of managed care in the heal th insurance industry. In 1988 about $8 \%$ of ind $\mathrm{i}$ viduals with heal th insurance were covered through a health maintenance organization (HMO), preferred provider organization (PPO), or point of service plan (POS). By 1996 this figure had increased to $33 \%$ (Lewin Group 1997). Throughout the $1990 \mathrm{~s}$, managed care enrollment increased at the rapid rate of about $11 \%$ per year for HMOs and about $13 \%$ per year for PPOs, so that in 1998 HMO enrollment was 78.8 million (Interstudy 1999). Both small and large firms are now likely to offer their employees at least one managed care plan (Jensen et al. 1997). One of the principal aims of managed care is, through competition and provider monitoring, to curb the high costs stemming from patient and physician moral hazard associated with standard fee-for-service insurance. Declines in the growth of health care costs have been driven in part by these changes in insurance and industry structure.

While the rise in managed care has been one of the most significant changes in the heal th care industry in recent years, it has not occurred uniformly across regions of the country. According to 1996 data from American Association of Heal th Plans, managed care provides about $78 \%$ of the com- 
mercial insurance market among the top 146 metropolitan statistical areas. This ranges from a high of $96 \%$ to a low of $43 \%$ across MSAs. Dranove et al. (1998) reported that, as of 1994, the share of physician revenues earned from managed care ranged from $17 \%$ to nearly $60 \%$ across cities with populations exceeding 1 million. Thus, one would expect regional variation in cost savings as well, or a greater likelihood of managed care where the opportunity for cost savings is greatest.

The emergence of managed care, together with other cost containment measures such as the Medicare Integrity Program and other initiatives to reduce fraud and abuse, has led to an overall slowdown in the heal th services industry. This in turn may have caused a slowdown in the nursing labor market. This slowdown need not be uniform, however, since the movement toward team nursing and accelerated care nursing (Gardner 1991), as well as other measures to achieve greater efficiency in the delivery of heal th care, may have placed greater emphasis on higher-skilled nurses than on lower-skilled nurses. I examine these issues below.

\section{Data}

The cross-sectional data for this paper are drawn from the monthly Current Population Survey (CPS) Earnings Files, conducted by the Bureau of the Census, from January 1988 through December 1998. Since the focus is on nursing earnings and employment patterns over the $1990 \mathrm{~s}$, the analysis is restricted to the years 1988 through 1998. (For analysis of earlier years, see, for example, Schumacher 1997.)

In order to make relative wage comparisons to RNs, I define two comparison groups. The first group consists of women with at least 16 years of education in the following broad occupational categories (excluding health occupations): executive, administrative, and managerial occupations; professional specialty occupations; technicians and related support occupations; sales occupations; administrative sup- port occupations, including clerical; and service occupations, except protective and household. This group is intended to capture economy-wide variations in earnings for women over the period. Next, I select all workers (other than RNs) in the health care industry. ${ }^{1}$ This group is intended to capture within-industry variations in earnings over the period. Where appropriate, I also compare RNs to licensed practical nurses (LPNs). I include all employed wage and salary workers aged 18 or over whose major activity was not schooling. The final samples are 33,028 RNs, 180,697 women in the non-health comparison group, and 142,281 men and women in the heal th care comparison group.

Table 1 displays real wages in 1998 dollars by year for RNs and the two comparison groups. It is apparent that the rapid wage growth experienced by RNs in the $1980 \mathrm{~s}$ did not continue throughout the 1990s. The average real wage for RNs increased from $\$ 17.78$ per hour in 1988 to $\$ 19.98$ by 1993, but declined after 1993; in 1997, it was $\$ 18.74$. The following year, however, it appears to have increased again, to about $\$ 19.20$. Both the growth of RNs' real wages over the 1988-93 period and the decline after 1993 were more pronounced for hospital RNs than for non-hospital RNs. In contrast, the health industry comparison group experienced moderate wage growth throughout the period. In that group, earnings of hospital workers declined slightly in the mid-1990s, but not to the extent that they did for RNs. Wages for all heal th care workers increased in 1998. The non-heal th comparison group also experienced relatively modest wage increases through most of the period, with a peak in

${ }^{1}$ The following Census industry categories were included: offices of physicians, offices of dentists, offices of chiropractors, offices of optometrists, offices of health practitioners, n.e.c., hospitals, nursing and personal care facilities, and health services, n.e.c. Omitted from this group were medical scientists, physicians, dentists, optometrists, and podiatrists, who are likely to have a high proportion of individuals with earnings topcoded in the CPS. 
Table 1. Real Wages of Registered Nurses and Comparison Groups, 1988-1998.

\begin{tabular}{|c|c|c|c|c|c|c|c|}
\hline \multirow[b]{2}{*}{ Year } & \multicolumn{3}{|c|}{ Registered Nurses } & \multicolumn{4}{|c|}{ Comparison Groups } \\
\hline & All & Hospital & Non-Hospital & Non-Health & Health & Hospital Health & $L P N s$ \\
\hline 1988 & $\$ 17.78$ & $\$ 18.38$ & $\$ 16.28$ & $\$ 15.54$ & $\$ 11.91$ & $\$ 12.84$ & 11.95 \\
\hline 1989 & 18.93 & 19.75 & 17.10 & 16.02 & 12.39 & 13.38 & 12.20 \\
\hline 1990 & 19.37 & 20.07 & 17.34 & 16.24 & 12.48 & 13.43 & 12.33 \\
\hline 1991 & 19.73 & 20.62 & 17.51 & 16.13 & 12.54 & 13.47 & 12.51 \\
\hline 1992 & 19.79 & 20.55 & 17.85 & 16.38 & 12.72 & 13.98 & 12.90 \\
\hline 1993 & 19.98 & 20.79 & 18.11 & 16.46 & 12.76 & 13.97 & 12.80 \\
\hline 1994 & 19.43 & 20.11 & 18.02 & 18.00 & 13.23 & 14.57 & 13.07 \\
\hline 1995 & 19.46 & 20.28 & 17.83 & 16.96 & 13.39 & 14.53 & 12.45 \\
\hline 1996 & 18.91 & 19.73 & 17.44 & 16.68 & 13.24 & 14.05 & 12.62 \\
\hline 1997 & 18.74 & 19.46 & 17.43 & 17.13 & 13.35 & 14.35 & 12.28 \\
\hline 1998 & 19.20 & 19.78 & 18.17 & 17.79 & 13.74 & 14.82 & 12.70 \\
\hline
\end{tabular}

Notes: Wages are in 1998 dollars. The non-health comparison group consists of college-educated women in non-health occupations. The health comparison group consists of all workers (excluding RNs) in health care industries.

Source: CPS ORG files, January 1988 through December 1998.

1994, a dip in 1995, and a substantial rise in 1997-98.

\section{Relative Wage Growth: 1988 to 1998}

In order to examine the real wage growth of nurses over the period, differences in worker and labor market characteristics must be accounted for. I do so by constructing an adjusted earnings index. For each group of workers, I estimate the equation

$$
\ln W_{i n}=\sum_{j=1}^{J} \beta_{j} X_{i n j}+\sum_{y=2}^{Y} \tau_{y} \operatorname{YEAR}_{i n y}+\varepsilon_{i n},
$$

where $\ln W_{i n}$ is the log real wage for worker $i$ in occupational group $n, X$ contains observed personal and job-related characteristics that affect the wage, $\beta$ contains their coefficients, and $\varepsilon$ is a well-behaved error term. Assuming a common structure of earnings over time (an assumption relaxed below), the coefficients on year dummies $(\tau)$ provide an estimate of log earnings differences by year after controlling for worker mix and other characteristics. The year coefficients are converted to a percentage index by the formula $\exp \left(\tau_{v}\right) * 100$.

Relative earnings are examined by estimating, for each year, the equation

$$
\ln W_{i y}=\sum_{j=1}^{J} \beta_{j} X_{i y j}+\delta_{y} \mathrm{RN}_{i y}+\varepsilon_{i y},
$$

where $\ln W_{i y}, X, \beta$, and $\varepsilon$ are defined as in equation (1), and $y$ indexes the year. RNs are pooled with the comparison group, and $\mathrm{RN}$ is a dummy variable equal to 1 if the worker is employed as an RN. The coefficient $\delta_{y}$ provides an estimate of the relative earnings differential between RNs and their comparison group for year $y$. This approach allows the earnings structure to vary over time, but restricts the structure to be the same for the nurses and their respective comparison group.

Table 2 displays the adjusted wage indices from 1988 to 1998 for RNs and the comparison groups $(1988=100)$. After adjusting for available characteristics, the analysis shows that RN real wages increased from 1988 to 1993 , so that an RN in 1993 earned $12 \%$ higher wages than a similar RN in 1988. Adjusted wages fell after 1993: an $\mathrm{RN}$ in 1997 earned $9.5 \%$ lower wages than a similar RN in 1993. This decline in wages was most severe for hospital RNs, for whom real wages fell by $10.7 \%$ between 1993 and 1997, whereas wages for non-hospital RNs fell by only $7.6 \%$ over this period. Also, wages fell more rapidly for RNs with less than 16 years of schooling (those with an associate or diploma degree) than for those with at least 16 years of schooling. Adjusted wages increased for nurses in 1998 by 3- 
Table 2. Adjusted Wage Indices: Registered Nurses and Comparison Groups, 1988-1998.

\begin{tabular}{|c|c|c|c|c|c|c|c|c|c|c|}
\hline \multirow[b]{2}{*}{ Year } & \multicolumn{5}{|c|}{ Registered Nurses } & \multicolumn{5}{|c|}{ Comparison Groups } \\
\hline & $\begin{array}{l}\text { All } \\
R N s\end{array}$ & Hospital & NonHosp & $\begin{array}{c}\text { School } \\
>16\end{array}$ & $\begin{array}{c}\text { School } \\
<16\end{array}$ & $\begin{array}{c}\text { Non } \\
\text { Health }\end{array}$ & Health & $\begin{array}{c}\text { Hospital- } \\
\text { Health }\end{array}$ & $L P N$ & $\begin{array}{l}\text { Hospital } \\
\text { LPN }\end{array}$ \\
\hline 1988 & 100.0 & 100.0 & 100.0 & 100.0 & 100.0 & 100.0 & 100.0 & 100.0 & 100.0 & 100.0 \\
\hline 1989 & 105.1 & 105.8 & 103.3 & 104.8 & 105.0 & 102.5 & 101.3 & 100.5 & 100.9 & 101.4 \\
\hline 1990 & 107.2 & 107.2 & 106.9 & 108.4 & 105.7 & 102.8 & 101.0 & 100.4 & 101.7 & 103.1 \\
\hline 1991 & 108.3 & 108.9 & 106.4 & 109.2 & 107.9 & 101.6 & 101.5 & 100.4 & 104.1 & 104.7 \\
\hline 1992 & 110.4 & 110.2 & 110.5 & 111.4 & 109.6 & 102.5 & 100.8 & 100.6 & 105.7 & 105.7 \\
\hline 1993 & 111.9 & 111.2 & 113.6 & 112.7 & 110.6 & 102.9 & 100.2 & 99.9 & 104.5 & 104.9 \\
\hline 1994 & 106.4 & 105.1 & 108.8 & 109.4 & 102.6 & 103.8 & 98.2 & 98.6 & 103.8 & 103.0 \\
\hline 1995 & 106.4 & 106.1 & 106.7 & 109.6 & 102.2 & 103.9 & 99.6 & 98.5 & 102.4 & 102.8 \\
\hline 1996 & 104.1 & 103.0 & 106.0 & 105.9 & 100.4 & 100.9 & 97.3 & 94.9 & 102.7 & 102.1 \\
\hline 1997 & 102.4 & 100.5 & 106.0 & 104.2 & 98.7 & 103.6 & 98.7 & 96.6 & 101.1 & 99.2 \\
\hline 1998 & 105.7 & 103.2 & 110.0 & 108.0 & 101.4 & 108.4 & 100.9 & 99.3 & 105.8 & 103.7 \\
\hline
\end{tabular}

Notes: The indices are derived from a separate log wage equation for each group including controls for years of schooling, potential experience and its square, and dummy variables for city size (6), gender, race (3), ethnic group, part-time status, marital status (2), region (8), and year (9). The coefficients on the year dummies are converted to a percentage index by $\exp (\beta) * 100$, where $\beta$ is the coefficient.

Source: CPS ORG files, January 1988 through December 1998.

$4 \%$, apparently ending the wage decline for RNs.

By contrast, the non-heal th comparison group of college-educated women experienced relatively constant or slightly increasing wages through 1997. Adjusted wages appear to have increased rather substantially $(4.8 \%)$ in 1998 for this group. The heal th care comparison group experienced stagnant wages up to 1993 , and wages continued to fall slightly thereafter. There is little difference between the wage growth in and out of hospitals for this group. LPNs experienced a small wage increase in the early 1990s, but wages declined afterward. Like wages for RNs, wages for LPNs increased substantially in 1998.

It is apparent that RNs experienced a decline in real wages during the 1990s relative to college-educated women. Such factors as the shift from fee-for-service to managed care health insurance plans and changes in federal reimbursement policies appear to have decreased the demand for RNs (Engel 1999). Note that this decline in real wages was not due to lower skill requirements among RNs or less hectic work in hospitals. In fact, just the opposite may have been occurring (Kilborn 1998), in which case the above analysis has understated the decline in wages.

Table 3 displays log wage differentials comparing RNs with each comparison group. Relative to college-educated women, RNs made wage gains up to 1993 , and then their relative wages fell. The decline was largest for hospital RNs. A hospital RN in 1993 is estimated to have earned .46 log points higher wages than a college-educated woman with similar characteristics. By 1998 this differential fell to $.32 \log$ points. For non-hospital RNs the differential fell from $.33 \mathrm{log}$ points in 1993 to $.22 \mathrm{log}$ points in 1998. Note that the increase in the wage index for RNs in 1998 (Table 2) does not appear in relative wages. That is, relative wages for RNs continued to decline in 1998, suggesting that while wages increased for RNs in 1998, they increased faster for college-educated women outside nursing.

RNs also experienced relative wage declines when compared to the health care control group starting after 1993. The log wage differential for RNs fell from .35 in 1993 to .26 in 1998. The declines were larger for hospital RNs, for whom the differential fell from $.42 \log$ points in 1993 to .31 in 1998, than for RNs outside hospitals, 
for whom the differential fell from .26 to .20. The decline in the relative wage differential also appears to have been lower for RNs with 16 years of education or more.

Table 4 shows nursing employment over the period. In $1988 \mathrm{RN}$ employment was 1.5 million, with 1.1 million employed in hospitals. RN employment increased over this period, reaching about 2.0 million in 1997. The increases were concentrated primarily in the early part of the period and in hospitals. After 1993, RN employment was fairly constant in hospitals, while there were increases in non-hospital employment through 1997. Employment in both sectors fell in 1998. This increase in relative nonhospital employment is consistent with stories of care moving out of hospitals and into non-hospital settings (Brider 1996; Engel 1999). The health care comparison group shows relatively steady employment increases in hospital employment early in the period, but in the later years employment growth was much stronger in non-hospital settings.

The relative wage declines and the slowdown in the growth of employment for RNs are consistent with a demand decrease, and the relatively larger declines for hospital $\mathrm{RNs}$ as well as the decline in relative employment are consistent with a particularly strong slowdown for RNs in hospitals. This likely reflects the increasingly competitive nature of health care markets in an era of concern over rising health care costs and the emergence of managed care.

\section{Understanding the Relative Wage Decline}

Overall, RN earnings decreased relative to earnings of the non-health comparison group by $2.2 \%$ per year over the 1993-98 period and by $1.9 \%$ per year when compared to the heal th care comparison group. In this section I attempt to gain a better understanding of this decline.

\section{A Decomposition of Wage Growth}

I first examine this relative wage decline more closely by constructing a decomposi- tion that separates the contributions of changes in relative quantities (the $X^{\prime}$ s) from changes in relative prices (the $\beta$ 's). I follow the procedure O'Neill and Polachek (1993) used to examine the change in the gender wage gap, by first estimating the following equation separately for RNs and the RN comparison group:

$$
\begin{gathered}
\ln W_{i n}=\sum_{j=1}^{J} \beta_{j} X_{i n j}+\alpha_{1} \operatorname{TIME}_{i}+ \\
\sum_{j=2}^{J} \delta_{j} X_{i n j} * \operatorname{TIME}_{i}+\varepsilon_{i n},
\end{gathered}
$$

where TIME is a linear time trend $(1993=1$, $1994=2, \ldots, 1998=6)$. Interacting TIME with the other right-hand-side variables allows an estimate of the change in the prices associated with these variables over time for each group. An equation without the time interaction terms is also estimated to get an estimate of the average return to each characteristic over the period. I then calculate the mean as well as the average annual change for each characteristic over the period. These estimates are used to decompose the decline in $\mathrm{RN}$ wages over the 1993-98 period, by separating out the proportion due to changes in the characteristics (quantities) and those due to changes in the coefficients (prices).

Equation (3) above (as well as equations 1 and 2) can be interpreted as a hedonic price function reflecting the equilibrium of the supply and demand for workers at each level of schooling, experience, and so on (Rosen 1974; Willis 1986). Alternatively, if one assumes that occupational supply curves are perfectly elastic in the long run (that is, that there is worker homogeneity in preferences and natural ability), then one can think of the wage equation as a structural price equation, with the wage determined entirely by supply shifters (skill, working conditions, and so on) and not influenced by demand. However, if, more realistically, these assumptions are relaxed, one can think of the wage equation as a reduced form equation whereby the wage is determined by supply and demand shifters.

Columns 1 and 3 of Table 5 take the average annual change in the variable and 
Table 3. Log-Wage Differentials, 1988-1998.

\begin{tabular}{|c|c|c|c|c|c|c|c|c|c|c|c|c|c|c|c|c|}
\hline \multirow[b]{3}{*}{ Year } & \multicolumn{8}{|c|}{ RNs and the Non-Health Comparison Group } & \multicolumn{8}{|c|}{$R N s$ and the Health Care Comparison Group } \\
\hline & \multicolumn{2}{|c|}{ All $R N$} & \multicolumn{2}{|c|}{ Hospital RN } & \multicolumn{2}{|c|}{ NonHosp. RN } & \multicolumn{2}{|c|}{ School > 16} & \multicolumn{2}{|c|}{ All $R N$} & \multicolumn{2}{|c|}{ Hospital Only } & \multicolumn{2}{|c|}{ NonHosp Only } & \multicolumn{2}{|c|}{ School $>16$} \\
\hline & Coeff. & $S E$ & Coeff. & $S E$ & Coeff. & $S E$ & Coeff. & $S E$ & Coeff. & $S E$ & Coeff. & $S E$ & Coeff. & $S E$ & Coeff. & $S E$ \\
\hline 1988 & .327 & .011 & .384 & .012 & .235 & .018 & .277 & .013 & .276 & .009 & .359 & .010 & .162 & .015 & .215 & .012 \\
\hline 1989 & .351 & .010 & .423 & .012 & .244 & .017 & .294 & .013 & .286 & .009 & .366 & .010 & .156 & .014 & .211 & .012 \\
\hline 1990 & .366 & .010 & .422 & .011 & .273 & .017 & .325 & .012 & .302 & .008 & .377 & .009 & .187 & .014 & .246 & .011 \\
\hline 1991 & .386 & .010 & .445 & .011 & .276 & .017 & .332 & .012 & .304 & .008 & .383 & .009 & .174 & .014 & .245 & .011 \\
\hline 1992 & .395 & .010 & .450 & .012 & .295 & .017 & .345 & .013 & .329 & .008 & .407 & .009 & .216 & .014 & .256 & .011 \\
\hline 1993 & .413 & .010 & .462 & .012 & .334 & .017 & .359 & .013 & .349 & .008 & .418 & .009 & .259 & .014 & .272 & .012 \\
\hline 1994 & .362 & .012 & .407 & .014 & .299 & .019 & .310 & .015 & .298 & .010 & .366 & .011 & .217 & .015 & .238 & .013 \\
\hline 1995 & .346 & .012 & .404 & .014 & .258 & .019 & .307 & .015 & .291 & .010 & .366 & .011 & .194 & .015 & .242 & .013 \\
\hline 1996 & .353 & .013 & .407 & .015 & .289 & .019 & .312 & .016 & .291 & .010 & .360 & .012 & .204 & .015 & .233 & .014 \\
\hline 1997 & .306 & .013 & .348 & .014 & .258 & .019 & .266 & .015 & .263 & .010 & .315 & .012 & .202 & .015 & .202 & .013 \\
\hline 1998 & .275 & .012 & .315 & .014 & .223 & .018 & .240 & .014 & .260 & .009 & .312 & .011 & .199 & .015 & .206 & .013 \\
\hline
\end{tabular}

Notes: Shown are the coefficients on a nursing dummy variable for which each nursing group is pooled with their respective comparison group. Separate regressions are run for each year. Other variables included in the regressions were years of schooling, potential experience and its square, and dummy variables for city size (6), gender, race (3), ethnic group, part-time status, marital status (2), and region (8).

Source: CPS ORG files, January 1988 through December 1998. 
Table 4. Health Care Employment, 1988-1998 (in thousands).

\begin{tabular}{|c|c|c|c|c|c|c|c|c|c|}
\hline \multirow[b]{2}{*}{ Year } & \multicolumn{3}{|c|}{$R N s$} & \multicolumn{3}{|c|}{$L P N s$} & \multicolumn{3}{|c|}{ Health Care Comparison } \\
\hline & All & Hosp & $\%$ Hosp & All & Hosp & $\%$ Hosp & All & Hosp & \% Hosp \\
\hline 1988 & 1,543 & 1,106 & 71.7 & 411 & 201 & 48.9 & 7,418 & 3,409 & 46.0 \\
\hline 1989 & 1,592 & 1,100 & 69.1 & 408 & 206 & 50.5 & 7,680 & 3,460 & 45.1 \\
\hline 1990 & 1,676 & 1,169 & 69.7 & 442 & 216 & 48.9 & 7,983 & 3,551 & 48.4 \\
\hline 1991 & 1,693 & 1,196 & 70.6 & 452 & 214 & 47.3 & 8,305 & 3,653 & 44.5 \\
\hline 1992 & 1,793 & 1,288 & 71.8 & 452 & 197 & 43.6 & 8,644 & 3,642 & 42.1 \\
\hline 1993 & 1,855 & 1,294 & 69.8 & 438 & 193 & 44.1 & 8,909 & 3,762 & 42.2 \\
\hline 1994 & 1,952 & 1,324 & 67.8 & 395 & 153 & 38.8 & 8,774 & 3,678 & 41.9 \\
\hline 1995 & 1,970 & 1,293 & 65.6 & 399 & 147 & 36.8 & 9,181 & 3,693 & 40.2 \\
\hline 1996 & 1,978 & 1,275 & 64.5 & 396 & 142 & 35.9 & 9,349 & 3,773 & 40.4 \\
\hline 1997 & 2,063 & 1,326 & 64.3 & 404 & 142 & 35.1 & 9,637 & 3,823 & 49.7 \\
\hline 1998 & 2,024 & 1,306 & 64.5 & 380 & 153 & 40.3 & 9,707 & 3,859 & 39.8 \\
\hline
\end{tabular}

Source: CPS ORG files, January 1988 through December 1998.

multiply it by the average coefficient over the pooled sample for each group $\left(\Delta X_{i} * \beta_{i}\right)$. The difference between these two products for RNs and the comparison group reflects the effect of the relative changes in the variable on relative earnings. Columns 2 and 4 take the average annual change in the coefficient (the time trend interactions from equation 3) and multiplies it by the average level of the variable over the period $\left(\Delta \beta_{i} * X_{i}\right)$. The difference between groups for this product indicates how changes in the prices associated with this variable affect relative earnings. Note that the decomposition in Table 5 separates the relative wage decline into those parts "explained" by price and quantity effects and those parts left unexplained. It does not decompose the demand effects from supply effects. If a particular variable is found to be an important determinant of the wage decline, however, one could speculate as to whether this is driven primarily by demandside or supply-side effects.

In Table 5 the first two columns compare RNs with the non-health comparison group. These figures indicate that changes in characteristics had little effect on the relative wage decline for RNs. The numbers in parentheses are the percentage of the total decline in relative earnings accounted for by this variable. The largest effect is the relative change in schooling, which resulted in a $0.2 \%$ increase per year in $\mathrm{RN}$ relative wages. Overall, changes in the $X$ 's suggest a slight increase in $\mathrm{RN}$ relative wages. Column 2 shows the degree to which changes in the returns to characteristics contributed to the relative wage decline. The table reveals the importance of the increasing returns to schooling for RNs. If the only change in the wage structure had been the relative change in the returns to schooling, RNs would have realized gains of $6.7 \%$ per year over the comparison group, not the $2.2 \%$ decline per year they experienced. Potential experience also acted to increase relative wages for $\mathrm{RNs}$ over the comparison group.

The largest single contributor to the relative wage decline is the decrease in the returns to hospital employment, which accounts for a $.5 \%$ per year decline in $\mathrm{RN}$ relative wages, or about $25 \%$ of the total decline in relative wages over the period. In results not shown, the hospital wage differential decreased from a high of about $20 \%$ in 1991 to a low of $11 \%$ in 1998 . Schumacher and Hirsch (1997) argued that a large part of the hospital wage differential is due to unmeasured skills and less pleasant or more demanding working conditions in hospitals (for example, shift work). They speculated that with the movement of care from the hospital to the nonhospital setting in recentyears, the hospital wage differential should decline owing to falling hospital wages and, possibly, rising 
Table 5. A Decomposition of RN Relative Wage Growth, 1993-1998.

\begin{tabular}{|c|c|c|c|c|}
\hline \multirow[b]{2}{*}{ Variable Description } & \multicolumn{2}{|c|}{ RN/Non-Health Comparison } & \multicolumn{2}{|c|}{ RN/Health Industry Comparison } \\
\hline & Effect of $\Delta X$ & Effect of $\Delta \beta$ & Effect of $\Delta X$ & Effect of $\Delta \beta$ \\
\hline \multicolumn{5}{|l|}{ School } \\
\hline RN & .002 & .034 & .002 & .034 \\
\hline Comparison & .000 & -.033 & .006 & .012 \\
\hline Difference $(\%)$ & $.002(-8.1)$ & $.067(-310.0)$ & $-.004(20.6)$ & $.022(-116.7)$ \\
\hline \multicolumn{5}{|l|}{ Experience } \\
\hline RN & .005 & .011 & .005 & .011 \\
\hline Comparison & .008 & .023 & .004 & .012 \\
\hline Difference (\%) & $-.002(10.4)$ & $-.013(58.3)$ & $.002(-8.5)$ & $-.002(8.5)$ \\
\hline \multicolumn{5}{|l|}{ Experience Squared } \\
\hline RN & -.004 & .001 & -.004 & .011 \\
\hline Comparison & -.006 & -.015 & -.002 & -.007 \\
\hline Difference $(\%)$ & $.002(-9.6)$ & $.016(-73.8)$ & $-.002(11.8)$ & $.008(-43.0)$ \\
\hline \multicolumn{5}{|l|}{ Union } \\
\hline RN & -.000 & .001 & -.000 & .001 \\
\hline Comparison & -.001 & .000 & -.000 & -.000 \\
\hline Difference $(\%)$ & $.001(-2.2)$ & $.000(-0.9)$ & $.000(-0.1)$ & $.001(-3.8)$ \\
\hline \multicolumn{5}{|l|}{ Hospital } \\
\hline $\mathrm{RN}$ & -.002 & -.005 & -.002 & -.005 \\
\hline Comparison & .000 & .000 & -.001 & -.004 \\
\hline Difference $(\%)$ & $-.002(2.1)$ & $-.005(24.7)$ & $-.001(5.5)$ & $-.001(7.6)$ \\
\hline \multicolumn{5}{|l|}{ Public Employment } \\
\hline RN & .000 & .000 & .000 & .001 \\
\hline Comparison & -.000 & -.002 & .000 & -.000 \\
\hline Difference (\%) & $.000(-1.5)$ & $.002(-11.2)$ & $.000(-0.0)$ & $.001(-2.7)$ \\
\hline \multicolumn{5}{|l|}{ Metropolitan Area } \\
\hline RN & -.000 & -.000 & -.000 & -.000 \\
\hline Comparison & .000 & .002 & .000 & -.002 \\
\hline Difference $(\%)$ & $-.001(2.9)$ & $-.002(8.6)$ & $-.000(2.0)$ & $.002(-8.2)$ \\
\hline \multicolumn{5}{|l|}{ Race/Ethnicity } \\
\hline RN & -.000 & .001 & -.000 & .001 \\
\hline Comparison & -.000 & -.000 & -.000 & .000 \\
\hline Difference $(\%)$ & $-.00(-0.3)$ & $.001(-6.7)$ & $.000(-0.6)$ & $.001(-3.6)$ \\
\hline \multicolumn{5}{|l|}{ Marital Status } \\
\hline RN & .002 & -.001 & .002 & -.001 \\
\hline Comparison & .000 & -.001 & -.000 & -.002 \\
\hline Difference $(\%)$ & $.002(-10.3)$ & $.000(-2.0)$ & $.002(-12.6)$ & $.001(-4.6)$ \\
\hline \multicolumn{5}{|l|}{ Region } \\
\hline RN & -.000 & .003 & -.000 & .003 \\
\hline Comparison & -.001 & .003 & -.000 & .004 \\
\hline Difference $(\%)$ & $.000(-1.4)$ & $.000(-1.1)$ & $-.000(0.4)$ & $-.001(6.6)$ \\
\hline Subtotal (\%) & $.003(-11.8)$ & $.068(-316.0)$ & $-.003(18.3)$ & $.032(-168.8)$ \\
\hline \multicolumn{5}{|l|}{ Residual Trend } \\
\hline RN & \multicolumn{2}{|c|}{-.059} & \multicolumn{2}{|c|}{-.059} \\
\hline Comparison & \multicolumn{2}{|c|}{.029} & \multicolumn{2}{|c|}{-.014} \\
\hline Difference $(\%)$ & \multicolumn{2}{|c|}{$-.087(403.7)$} & \multicolumn{2}{|c|}{$-.044(234.4)$} \\
\hline Subtotal $(\%)$ & \multicolumn{2}{|c|}{$-.016(75.9)$} & \multicolumn{2}{|c|}{$-.016(83.9)$} \\
\hline Gap & & $4.1)$ & & $03(16.1)$ \\
\hline Total & & $\frac{100)}{100)}$ & & $19(100)$ \\
\hline
\end{tabular}

This table provides a decomposition for the annual decline in relative earnings for RNs between 1993 and 1998 . The first two columns decompose the $2.2 \%$ annual decline in relative earnings between RNs and the non-health care comparison group. The second two columns decompose the $1.9 \%$ annual decline in relative earnings between RNs and the health care comparison group. For each, the first column multiplies the average annual change in the variable by the average coefficient on that variable over the entire period. The difference is the RN effect less the comparison group effect. The numbers in parentheses are the percentage of the total decline in relative earnings accounted for by this variable. The second column takes the average annual change in the coefficient (calculated by interacting the variable with a linear time trend) and multiplies it by the average for the variable over the period. Again, the numbers in parentheses indicate the percentage of the total decline accounted for by the change in the coefficients associated with this variable. For Race/Ethnicity, Marital Status, and Region, the table numbers are the aggregate effects for all the variables in these categories. 
non-hospital wages. The evidence here suggests that there has been a significant decline in the differential for hospital RNs. These results, together with the findings of slower employment growth in hospitals than in non-hospital settings, are consistent with a decline in demand for hospital RNs.

Results are similar when we compare RNs to the health care comparison group. Changes in characteristics account for about $18 \%$ of the wage decline, while changes in the return to those characteristics predict wages should have increased. The returns to measured skills (experience and schooling) increased substantially for RNs relative to the comparison group. The higher returns to measured skills suggest that RNs should have received overall wage gains of $3.2 \%$ per year when compared to the health care comparison group, not the $1.9 \%$ per year decline they actually experienced. Hospital employment explains a much smaller share of the relative wage decline than it does for the non-health comparison group, suggesting that the falling hospital differential was common across all occupations, not unique to RNs.

Differences in the residual trend (the coefficient on the time variable) in earnings are large, and make up by far the largest component of the wage decline for $\mathrm{RNs}$ relative to both comparison groups. That is, changes in measured characteristics and the return to those characteristics cannot explain the relative wage decline for RNs. In fact, these variables suggest wages should have increased for RNs by about $7.1 \%$ per year relative to the non-health comparison group and by about $3.5 \%$ per year relative to the health care comparison group. Thus, the results in Table 5 suggest that, while the decline in relative wages is consistent with an overall decline in demand for RNs over this period, it also indicates an increasing return to skill in the market for nurses, evinced by the faster relative growth in the return to schooling and experience for RNs than for the comparison groups.

\section{The Effects of Managed Care on Earnings}

While the results above are consistent with a demand decrease, they provide no direct evidence of that trend. I now examine the relationship between RN earnings and the presence of managed care health insurance. It is widely believed that the rise of managed care throughout the 1990s played a major role in slowing the increase in health care costs, and this may well have decreased the relative earnings of RNs. Buerhaus and Staiger (1996) examined the relationship between nursing employment and earnings and managed care over the 1983-94 period by separating states into those with high and low rates of enrollment in health maintenance organizations. They found that managed care was associated with slower growth in employment for RNs, but they did not find an effect for wages.

Spetz (1999) examined whether HMOs caused reductions in nursing staffing by estimating labordemand equations for RNs, LPNs, and aides in California short-term hospitals from 1976 to 1994 . She found that HMOs had affected the demand for LPNs and aides much more than the demand for RNs. HMO penetration is not directly related to $\mathrm{RN}$ hospital employment, but there is an indirect effect, since HMOs reduce the use of hospital services, which leads to a drop in demand for nursing personnel. Simon, Dranove, and White (1998) examined the relationship between physician compensation and the growth of managed care at the state level. They found that managed care growth was associated with a decrease in the earnings of specialists relative to primary care physicians, consistent with a reduction in market-level demand for specialty services.

I use data on HMO penetration by metropolitan statistical area over the years 199098 to examine the effect of HMOs on wages. ${ }^{2}$ These data were obtained by summing

\footnotetext{
${ }^{2}$ These data were kindly provided by Lawrence Baker at Stanford University.
} 
county-level HMO enrollment over all the HMOs serving the county. HMO market share was computed by obtaining the ratio of enrollees to the Census Bureau estimate of the total county population, and then aggregating to the MSA level. I merge MSAs into CMSAs where applicable, since doing so will more accurately reflect the extent of the local labor market. The final measure of HMO market share used in this analysis is obtained by applying a kernelsmoothing algorithm to HMO market share over time. (For more information about these data, see Baker [1995] or Baker and Brown [1999].) HMO market share by MSA increased relatively steadily over the period, from an average of about $12.6 \%$ in 1990 to $23.1 \%$ in 1998 . The standard deviation of HMO market share by MSA remained relatively stable between about .11 and .13 over the period.

I take two approaches to examining the association between $\mathrm{HMO}$ penetration and $\mathrm{RN}$ earnings. I first replicate the decomposition analysis above over the 1993-98 period by including the HMO market share variable as a right-hand-side variable. Since the HMO data are MSA-specific, I can only conduct the analysis for workers in large MSAs (1990 population greater than $100,000)$. Since measurement error in the HMO data is a concern, I use the two-year moving average of HMO MSA market share in this analysis. ${ }^{3}$

The results, presented in Table 6 , show that changes in HMO market share $(\Delta X)$ explain a small portion of the relative wage decline for RNs, while changes in the HMO wage effect $(\Delta \beta)$ explain a larger effectespecially for the non-health comparison group. HMOs are associated with about a $1.1 \%$ annual decline in $\mathrm{RN}$ wages relative to wages of the non-health group and about a $.5 \%$ annual decline relative to wages of the health care comparison group. There is, however, still a large unexplained component to the relative wage decline that

\footnotetext{
${ }^{3}$ Similar results are obtained if I use lagged HMO market share.
}

dominates the other effects. Thus, while it appears that HMO penetration may have had a small effect on $\mathrm{RN}$ wages, it cannot explain the large relative wage decline for RNs. The hospital effect remains relatively strong when HMO market share is included, suggesting that the hospital wage differential is not due to the changing composition of the insurance market.

I next examine the effect of HMO market share on RN wages more directly by conducting a two-stage estimation process. I first estimate an RN wage equation similar to the equations above, but including a set of MSA dummy variables interacted with three year groups (1990-92, 1993-95, and 1996-98). ${ }^{4}$ These estimates are then used in a second-step regression relating the MSA wage differential to MSA-specific measures of market conditions. That is, first the following equation is estimated:

$$
\begin{gathered}
\ln W_{i t k}=\sum_{j=1}^{J} \beta_{j} X_{i t k j}+\sum_{t=2}^{T} \delta_{t} \operatorname{TIME}_{t i k}+ \\
\sum_{k=2}^{K} \phi_{k t} \mathrm{MSA} * \operatorname{TIME}_{k i t}+\varepsilon_{i t k},
\end{gathered}
$$

where $\ln W_{i t k}$ is the natural logarithm of hourly earnings of worker $i$ in time period $t$ in labor market (MSA) $k$; $X$ includes individual-specific variables (indexed by $j$ ) affecting RN wages, with $\beta_{j}$ the attaching coefficients; MSA is a set of dummy variables corresponding to the CMSA/MSAs; and TIME is a set of dummy variables for the three time periods. The set of coefficients $\phi_{k t}$ measures the $\mathrm{RN}$ wage differential across MSAs and over time, and is used as the dependent variable in the second-step (weighted least squares) equation. This equation takes the form

$$
\begin{gathered}
\phi_{k l}=\alpha+\gamma \mathrm{HMO}_{k t}+\varepsilon \operatorname{ADMIS}_{k t}+\theta \mathrm{MDs}_{k t}+ \\
\operatorname{\kappa lnPOP}_{k t}+\operatorname{vPERIOD}_{\iota}+\varepsilon_{k},
\end{gathered}
$$

\footnotetext{
${ }^{4}$ Since there are about $3,000 \mathrm{RNs}$ in the data set for each year, it is not possible to estimate MSA dummies for each year separately. Even with three-year groups, many of the smallest MSAs contained empty cells and coefficients could not be estimated.
} 
Table 6. Decomposition of the Effect of HMO Growth on RN Relative Wage Growth, 1993-1998.

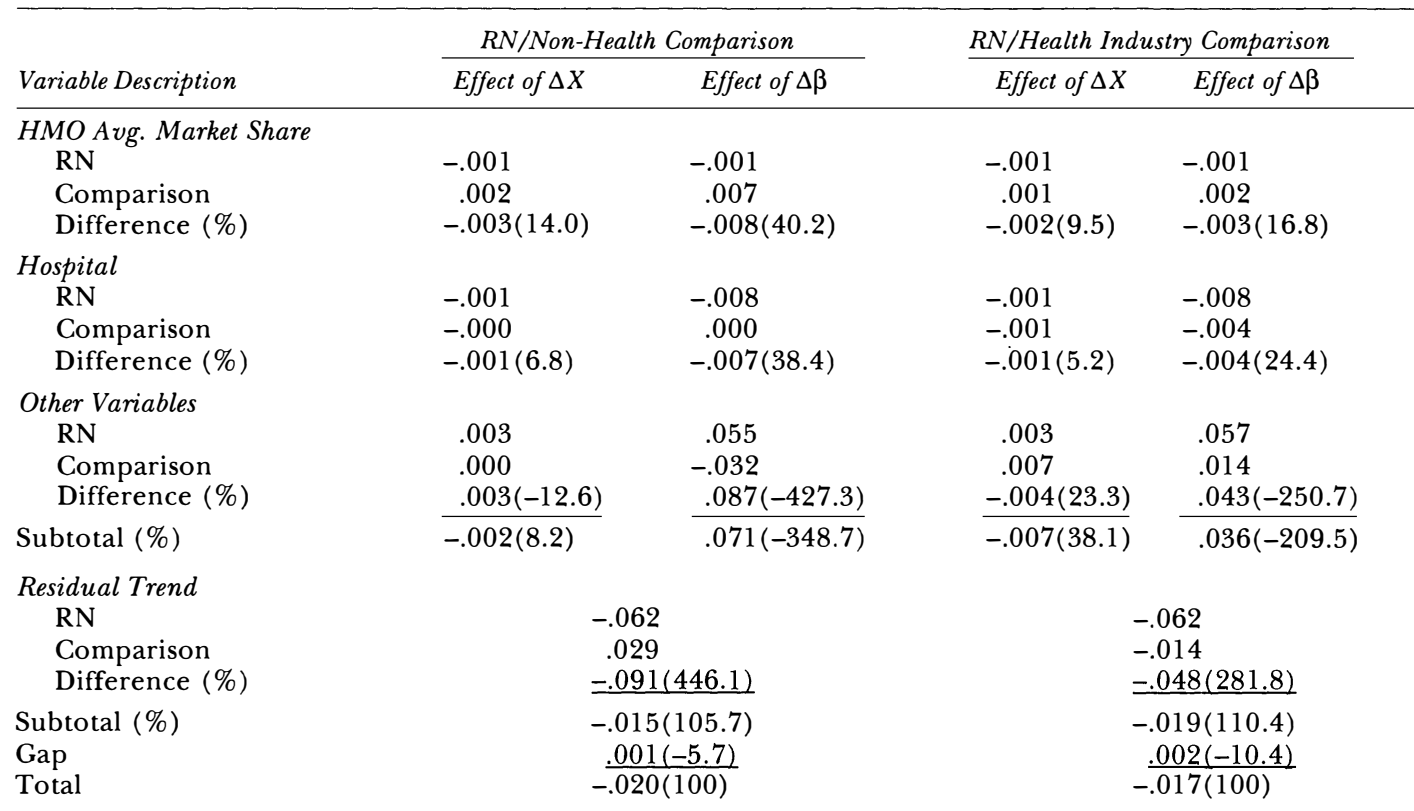

This table provides a decomposition for the annual decline in relative earnings for RNs between 1993 and 1998. The sample is restricted to large metropolitan statistical areas for which HMO penetration data are available. The analysis is identical to that presented in Table 5. Average HMO market share is the two-year moving average of HMO market share in the worker's MSA. The first two columns decompose the $2.0 \%$ annual decline in relative earnings between RNs and the non-health care comparison group. The second two columns decompose the $1.7 \%$ annual decline in relative earnings between RNs and the health care comparison group. For each, the first column multiplies the average annual change in the variable by the average coefficient on that variable over the entire period. The difference is the RN effect less the comparison group effect. The numbers in parentheses are the percentage of the total decline in relative earnings accounted for by this variable. The second column takes the average annual change in the coefficient (calculated by interacting the variable with a linear time trend) and multiplies it by the average for the variable over the period. Again, the numbers in parentheses indicate the percentage of the total decline accounted for by the change in the coefficients associated with this variable.

where $\phi_{k t}$ is the wage differential in MSA $k$ in time period $t$, HMO is the HMO penetration variable, ADMIs is per capita hospital admissions, MDs is per capita MDs, $\ln$ PoP is the log of MSA population, and PERIOD represents dummy variables for two of the three year groups.

Coefficients from the first-step regression capture within-area effects owing to variation across individuals in measurable characteristics, with fixed area/year wage effects measured by coefficients on the area dummy variables. Differences in area wage differentials are explained, in turn, by HMO penetration, hospital admissions, the num- ber of physicians, and MSA size. If HMOs have been able to lower RN wages in MSAs where HMO presence is strongest, we ought to see a negative and statistically significant estimate of the coefficient $\gamma .^{5}$

\footnotetext{
${ }^{5}$ Estimating the effects of HMO market share on $\mathrm{RN}$ wages can also be done using a one-step approach by simply including measures of HMO market share on the right-hand-side of the wage equations. Estimates indicate similar results, but standard errors from this procedure are potentially downward-biased (Moulton 1990).
} 
Table 7. The Effects of Managed Care on RN Wages.

\begin{tabular}{|c|c|c|c|c|c|c|c|c|}
\hline \multirow[b]{2}{*}{ Variable Description } & \multicolumn{4}{|c|}{ Registered Nurses } & \multicolumn{4}{|c|}{ Health Care Comparison } \\
\hline & $\begin{array}{c}1 \\
\text { Levels }\end{array}$ & $\begin{array}{c}2 \\
\text { Levels }\end{array}$ & $\begin{array}{c}3 \\
\text { Lagged }\end{array}$ & $\begin{array}{c}4 \\
\text { Change }\end{array}$ & $\begin{array}{c}1 \\
\text { Levels }\end{array}$ & $\begin{array}{c}2 \\
\text { Levels }\end{array}$ & $\begin{array}{c}3 \\
\text { Lagged }\end{array}$ & $\begin{array}{c}4 \\
\text { Change }\end{array}$ \\
\hline HMO Market Share & $\begin{array}{l}.080 \\
(.047)\end{array}$ & $\begin{array}{l}-.094 \\
(.054)\end{array}$ & $\begin{array}{l}-.057 \\
(.074)\end{array}$ & $\begin{array}{c}-.077 \\
(.171)\end{array}$ & $\begin{array}{l}.142 \\
(.046)\end{array}$ & $\begin{array}{c}-.091 \\
(.036)\end{array}$ & $\begin{array}{l}-.081 \\
(.047)\end{array}$ & $\begin{array}{l}-.046 \\
(.090)\end{array}$ \\
\hline Per Capita Admissions & - & $\begin{array}{l}-.235 \\
(.155)\end{array}$ & $\begin{array}{l}-.223 \\
(.205)\end{array}$ & $\begin{array}{c}-.031 \\
(.884)\end{array}$ & - & $\begin{array}{c}-.067 \\
(.103)\end{array}$ & $\begin{array}{c}-.085 \\
(.134)\end{array}$ & $\begin{array}{c}.545 \\
(.450)\end{array}$ \\
\hline$($ Per Capita MDs) $* 1000$ & - & $\begin{array}{l}.011 \\
(.006)\end{array}$ & $\begin{array}{l}.010 \\
(.008)\end{array}$ & $\begin{array}{c}-.034 \\
(.040)\end{array}$ & - & $\begin{array}{c}.008 \\
(.004)\end{array}$ & $\begin{array}{l}.005 \\
(.005)\end{array}$ & $\begin{array}{l}-.020 \\
(.021)\end{array}$ \\
\hline Log Population & - & $\begin{array}{l}.026 \\
(.006)\end{array}$ & $\begin{array}{c}.024 \\
(.007)\end{array}$ & $\begin{array}{c}-.164 \\
(.222)\end{array}$ & - & $\begin{array}{c}.043 \\
(.004)\end{array}$ & $\begin{array}{c}.042 \\
(.005)\end{array}$ & $\begin{array}{c}.159 \\
(.115)\end{array}$ \\
\hline Year 1993-1995 & $\begin{array}{c}.079 \\
(.009)\end{array}$ & $\begin{array}{l}.158 \\
(.011)\end{array}$ & - & - & $\begin{array}{c}.096 \\
(.009)\end{array}$ & $\begin{array}{c}.242 \\
(.007)\end{array}$ & - & - \\
\hline Year 1996-1998 & $\begin{array}{c}.044 \\
(.010)\end{array}$ & $\begin{array}{l}.125 \\
(.012)\end{array}$ & $\begin{array}{c}-.036 \\
(.012)\end{array}$ & - & $\begin{array}{c}.096 \\
(.010)\end{array}$ & $\begin{array}{l}(.247) \\
(.008)\end{array}$ & $\begin{array}{l}.003 \\
(.008)\end{array}$ & - \\
\hline
\end{tabular}

Results presented are from a second-step weighted least squares regression in which the coefficient on the MSA dummy variable interacted with the three year group dummies is the dependent variable. The inverse of the standard error from this first step coefficient is the weight. Columns 1 and 2 are levels equations; in column 3 , the right-hand-side variables are the values for the prior three-year period. Column 4 estimates a change equation, in which the dependent variable is the change in the MSA coefficient between the 1996/1998 period and the 1990/1992 period, and the right-hand-side variables are the change in the MSA level characteristic over the same time.

All health care statistics except the HMO market share variable are obtained from the Bureau of Health Professions' Area Resource File. This second-step regression is run using weighted least squares, where the inverse of the standard error from the first-step regression is the weight. This corrects for the fact that larger MSAs will have more (first-step) observations and, therefore, the coefficient in the first-stage regression will be estimated more precisely than that for smaller MSAs. ${ }^{6}$

The second-step results are presented in Table 7 for both RNs and the health care comparison group. The first column includes HMO market share and year group dummies, but no other characteristics; the results show a positive relationship between HMO market share and RN wages. When the other health care characteristics are

\footnotetext{
${ }^{6}$ Similar results are obtained if I use $\sqrt{ } n$ as the weight, where $n$ is the total sample size in the MSA for the first-step regression.
}

added to the model, however, this coefficient becomes negative. There is a marginally statistically significant negative relationship between $\mathrm{RN}$ wages and $\mathrm{HMO}$ market share-a one standard deviation increase in HMO market share (.12) is associated with about a $1 \%$ decrease in $\mathrm{RN}$ wages. While this effect is (marginally) statistically significant, it is relatively small, and is virtually identical to the effect for the health care comparison group. The difference between columns 1 and 2 indicates that the $\mathrm{HMO}$ variable is capturing some of the market conditions in column 1 , and this effect is mitigated as more characteristics are added to the model.

The results in column 3 of Table 7 are from a specification testing whether managed care penetration acts with a lag on the wages of health care workers. It may take some time for managed care's presence to affect the wages of workers in the market. In this specification the right-hand-side variables are lagged by one year-group. The dependent variable is the MSA coefficient in one of twoyear-groups (1993/95 or 1996/ 
98), and the independent variables are the MSA characteristic in year group 1990/92 or 1993/95. The results for RNs indicate that the coefficient estimate on the HMO market share variable is slightly lower than the levels estimate, and it is no longer statistically significant. For other health care workers, however, the effect is similar to the levels estimate. Thus, it does not appear that HMOs have a large lagged effect on the earnings of health care workers.

The estimates in columns 2 and 3 of Table 7 are an attempt to control for other MSA-level characteristics. The estimated HMO effect, while quite small, could potentially be due to other omitted factors, such as community tastes or income. While the HMO data allow the estimation of a detailed fixed effects model, year-to-year variations in $\mathrm{HMO}$ penetration could reflect the presence of measurement error in the HMO data, rather than true changes (Baker and Brown 1999).

In order to minimize the effects of this measurement error, I examine the change in the MSA coefficient between the 1990/ 1992 period and the 1996/1998 period. The change in the differential is used as the dependent variable and the right-hand-side variables are the changes in the MSA characteristics over this period. Examining changes over a long time period mitigates the effect of measurement error in HMO share and allows for adjustment time.

Column 4 of Table 7 shows this wage change equation for RNs and the health care comparison group. For RNs, the coefficient on HMO market share remains relatively stable, but the standard error is much larger, so that the effect is not statistically different from zero. In fact, none of the coefficient estimates are statistically significant in the change equation. The results of these models indicate that HMO levels affect RN wages slightly, but this effect goes to zero in the wage change equation due to measurement error combined with unmeasured community effects. Stated another way, even if the levels effect were found to be robust with respect to the wage change equation, the point estimate suggests that the HMO effect is very small economically,
Table 8. The HMO Effect over Time.

\begin{tabular}{lcc}
\hline Variable Description & $\begin{array}{c}\text { Registered } \\
\text { Nurses }\end{array}$ & $\begin{array}{c}\text { Health Care } \\
\text { Comparison }\end{array}$ \\
\hline HMO Market Share* & -.053 & .009 \\
(1990-1992) & $(.088)$ & $(.057)$ \\
HMO Market Share* & -.059 & -.113 \\
(1993-1995) & $(.091)$ & $(.059)$ \\
HMO Market Share* & -.155 & -.147 \\
(1996-1998) & $(.085)$ & $(.056)$ \\
\hline
\end{tabular}

The regression is a second-step regression similar to that presented in Table 7, except the HMO market share variable is interacted with the three year group dummies. The other variables included in the regression are per capita hospital admissions, per capita MDs, and the log of the population, all interacted with the year group dummies, as well as two of the three year group dummies.

and that variations in $\mathrm{HMO}$ penetration across markets and over time cannot explain much if any of the relative wage decline for RNs. ${ }^{7}$

I next interact the right-hand-side variables with the three year-group dummies in order to allow the effects of these variables to change over time. The coefficient estimates on the HMO market share variables are reported in Table 8 . The results show that the effects of HMO market share increased (became more negative) over the period for both RNs and the comparison group. For both groups the effect is statistically significant only in the last three years of the survey, and it is still rather small.

While the effect is small, the finding of a statistically significant effect in the later years but not in the early years makes sense for a number of reasons. First, one cannot rule out the possibility of a simultaneous relationship between managed care and earnings. For example, managed care may result in lower $\mathrm{RN}$ wages due to more binding cost constraints, but its adoption also

${ }^{7}$ I also estimated levels equations and included MSA dummy variables (community fixed effects) on the right-hand side. Results are highly similar to those presented in the wage change regressions. 
may be most likely where $\mathrm{RN}$ wages are "high." In addition, adoption of managed care may have a gradual rather than immediate impact on wages. The results for 1996-98 should capture the effect of past adoption of managed care on current wage levels. The lagged specification in Table 7, however, does not support this interpretation.

A more direct interpretation of these results is that only in recent years, as managed care has become the "dominant" sector, has it been able to affect wages. When HMOs' penetration was small and RN employment was growing, RNs could work for non-HMOs, so HMOs had to pay going wages. With employment stagnant and HMOs having much of the market, they can pay lower wages and still hire employees. ${ }^{8}$

The finding of a relatively small wage effect across MSAs due to HMO penetration is consistent with previous research and with theoretical prediction. If RNs are sufficiently mobile across MSAs, then if HMOs are able to lower $\mathrm{RN}$ wages in a particular MSA, the supply curves should adjust so that relative wages across MSAs equalize. ${ }^{9}$ Thus HMOs may lower the overall wage for RNs but will not affect the differentials across MSAs. Differences will arise, however, in employment levels-consistent with the findings of both Spetz (1999) and Buerhaus and Staiger (1996). Thus, it is possible that HMO penetration has substantially lowered RN wages, but RNs are sufficiently mobile so that these differences do not show up across MSAs.

\section{Conclusions}

I have examined the earnings and employment of RNs between 1988 and 1998, a

\footnotetext{
${ }^{8}$ The inclusion of MSA fixed effects in these models, again, indicates that the effect may be driven by community characteristics. The coefficient for RNs on the first two year groups stays relatively constant, but the effect for the last year falls from -.155 to -.093 and is not statistically significant.

${ }^{9}$ For similar evidence on wage differentials between RNs and college-educated women, see Hirsch and Schumacher (1995).
}

period during which demand growth slowed, particularly within hospitals. I find that beginning in $1993 \mathrm{RN}$ real wages declined both in absolute terms and also relative to wages of college-educated women and those of other workers in the health care industry. Estimates that do not adjust for changes in or returns to characteristics show that RNs experienced relative wage declines of $2.2 \%$ per year compared to college-educated women and $1.9 \%$ per year compared to other workers in the health care industry.

A decomposition of the relative wage loss for RNs suggests that most of that relative decline is not accounted for by changes in relative characteristics or in relative coefficients. This finding is consistent with the hypothesis that the relative decline was due to shrinking demand for RNs. The decompositions also reveal a statistically significant increase in the relative returns to schooling and experience for RNs over the period, which is consistent with stories of skill-upgrading in hospitals (Kilborne 1998).

An analysis that explores links between the earnings of RNs and the presence of managed care in the industry provides suggestive evidence that cost constrain ts played a small role in the wage decline. HMO penetration can account for about a $1.1 \%$ annual decline in $\mathrm{RN}$ wages relative to wages of the non-health comparison group and about a $.5 \%$ annual decline relative to wages of the heal th care comparison group. There remains, however, a rather large unexplained component to the relative wage decline for RNs.

I estimate a small negative relationship between $\mathrm{HMO}$ market share and RN wages, with a one standard deviation increase in HMO market share resulting in about a $1 \%$ decline in RN wages. A similar effect is found for the health care comparison group. I also find that this effect may have been stronger in the later part of the period than in the earlier part. The effect, however, is rather small, and its weak statistical significance disappears when community effects are controlled for with a wage change specification. These results suggest that 
HMOs were not directly responsible for the large relative wage decline experienced by RNs. It is possible, however, that HMOs contributed to a decline in overall wages for RNs, and that RNs' mobility prevented this wage decline from appearing across MSAs.

Beyond simply describing the trends in the nursing labor market over the past decade, this paper gives insight into the complex and dynamic workings of the health care industry. This period witnessed frequent calls for increased regulation; concern over rapidly rising costs; restructuring of the private health insurance industry; and changes in Medicare and Medicaid policy. These events had a great impact on the delivery of health care: hospital mergers increased rapidly, outpatient clinics arose to compete directly with hospitals, managed care plans changed the way hospitals and doctors do business, and so on. The results here suggest that the nursing labor market was also affected. The overall decline in real and relative wages for $\mathrm{RNs}$ along with an increase in the return to nursing skills indicates the increasingly competitive nature of the health care industry as hospitals are pushed by both private and public third-party payers to limit costs.

Previous literature (Schumacher 1997; Krall 1995; Walton 1997) has speculated that demand changes played a large role in $\mathrm{RN}$ wages. Since these papers were examining periods of largely increasing wages and increasing demand, however, inferences about the role of demand have not been compelling. This paper provides additional insight in to the role of demand by examining a period of slower growth in health expenditures and slower growth in hospital employment relative to non-hospital employment. The evidence presented here supports the inference that demand effects are important, since relative wages fell among hospital and non-hospital nurses, but more so among the latter group.

\section{REFERENCES}

Baker, Laurence C. 1995. "County-Level Measures of HMO Enrollment and Market Share." Mimeo, Department of Health Research and Policy, Stanford University.

Baker, Laurence C., and Martin L. Brown. 1999. "Managed Care, Consolidation among Health Care Providers, and Health Care: Evidence from Mammography." RAND Journal of Economics, Vol. 30, No. 2 (Summer), pp. 351-74.

Brider, Patricia. 1996. "Huge Job-Loss Projections Shock Health Professions." American Journal of Nursing, Vol. 96, No. 1 (January), pp. 61, 64.

Buerhaus, Peter I., and Douglas O. Staiger. 1996. "Managed Care and the Nurse Work Force." Journal of the American Medical Association, Vol. 276, No. 18 (November), pp. 1487-93.

Dranove, David, Carol J. Simon, and William D. White. 1998. "Determinants of Managed Care Penetration." Journal of Health Economics, Vol. 17, No. 6 (December), pp. 729-45.

Engel, Cynthia. 1999. "Health Services Industry: Still a Job Machine?" Monthly Labor Review, Vol. 122, No. 3 (March), pp. 3-14.

Freudenheim, Milt. 1998. "Dominance of Managed Care Grows in Workplace." New York Times, January 20, World Wide Web edition.

Gardner, K. 1991. "A Summary of Findings of a FiveYear Comparison Study of Primary and Team Nurs- ing." Nursing Research, Vol. 40, No. 2, pp. 113-17.

Hirsch, Barry T., and David A. Macpherson. 1999. Union Membership and Earnings Data Book: Compilations from the Current Population Survey 1999 Edition. Washington, D.C.: Bureau of National Affairs.

Hirsch, Barry T., and Edward J. Schumacher. 1995. "Monopsony Power and Relative Wages in the Labor Market for Nurses." Journal of Health Economics, Vol. 14, No. 4 (November), pp. 443-76.

Interstudy. 1999. The Competitive Edge. St. Paul, Minn.: Industry Report, Interstudy Publications, April.

Jensen, Gail A., Michael A. Morrisey, Shannon Gaffney, and Derek K. Liston. 1997. "The New Dominance of Managed Care: Insurance Trends in the 1990s." Health Affairs, Vol. 16, No. 1 (January/February), pp. 125-36.

Kilborn, Peter T. 1998. “'Accelerated-Care Nurses': More Work, Less Interaction with Patients." New York Times, April 9, World Wide Web edition.

Krall, Lisi. 1995. "The Rise and Fall of Customary Wages Differentials among Nursing Personnel in US Hospitals, 1956-1985." Cambridge Journal of Economics, Vol. 19, No. 3 (June), pp. 405-19.

Lewin Group, Inc. 1997. Managed Care Savings for Employers and Households, 1990 through 2000. Prepared for the American Association of Health Plans, May 23. 
Moulton, Brent R. 1990. "An Illustration of a Pitfall in Estimating the Effects of Aggregate Variables on Micro Units." Review of Economics and Statistics, Vol. 72, No. 2 (May), pp. 334-38.

O'Neill, June, and Solomon Polachek. 1993. "Why the Gender Gap in Wages Narrowed in the 1980s." Journal of Labor Economics, Vol. 11, No. 1, Part 1 (January), pp. 205-28.

Rosen, Sherwin. 1974. "Hedonic Prices and Implicit Markets: Product Differentiation in Pure Competition." Journal of Political Economy, Vol. 82, No. 1 (January/February), pp. 34-55.

Schumacher, Edward J. 1997. "Relative Wages and the Returns to Education in the Labor Market for Registered Nurses." In Solomon W. Polachek, ed., Research in Labor Economics, Vol. 16. Greenwich, Conn.: JAI Press, pp. 149-76.

Schumacher, Edward J., and Barry T. Hirsch. 1997. "Compensating Differentials and Unmeasured Ability in the Labor Market for Nurses: Why Do Hospitals Pay More?" Industrial and Labor Relations Review,
Vol. 50, No. 4 (July), pp. 557-79.

Simon, Carol J., David Dranove, and William D. White. 1998. "The Effect of Managed Care in the Incomes of Primary Care and Specialty Physicians." Health Services Research, Vol. 33, No. 3, Part 1 (August), pp. 549-69.

Spetz, Joanne. 1999. "The Effects of Managed Care and Prospective Payment on the Demand for Hospital Nurses: Evidence from California." Health Services Research, Vol. 34, No. 5, Part 1 (December), pp. 993-1010.

Walton, Surrey. 1997. "An Economic Analysis of the Market for Registered Nurses." Unpublished manuscript. Chicago: Department of Pharmacy Administration, University of Illinois, March.

Willis, Robert J. 1986. "Wage Determinants: A Survey and Reinterpretation of Human Capital Earnings Functions." In Orley Ashenfelter and Richard Layard, eds., Handbook of Labor Economics, Vol. 1. Amsterdam: Elsevier Science Publishers BV, pp. 525-602. 